\title{
AfterMath: Anthropological Data from Prisoner-of-War Camps
}

\author{
BRITTA LANGE
}

Anthropology was a largely philosophical enterprise in the eighteenth century, but, by the mid-nineteenth century, examinations of the human body began to disentangle themselves from the humanities. This branch, known then as "physical anthropology" in the German Empire, belonged to the natural sciences and was closely associated with Rudolf Virchow. Its exponents focused on describing and measuring physical characteristics, constructing complex patterns in order to distinguish themselves from investigators in anatomy, ethnology (defined as analyzing the culture of human "types"), and the emerging field of genetics. Physical anthropologists tried to identify human "racial characteristics" and "racial types" using the methods of anthropometrics or biometrics and of comparative morphology. These promised to provide a systematics of human "types" modeled on zoological systematics, which were to allow clear-cut "racial diagnoses."

This chapter presents two ways in which anthropology attempted to achieve a "racial diagnosis." Both attempts took their data from a comparable infrastructure: German and Austrian prisoner-of-war (POW) camps during World War I, which promised unimpeded access to their research objects under ideal working conditions ("Project Planning"). But in fact, the researchers, gathering their data following nearly identical criteria, faced an unexpectedly high number of problems ("Realization"). With regard to data interpretation, German scientists focused on measurements, conducting their analysis via statistics, whereas Austrian scientists relied on "anthropological seeing" and descriptions of physical characteristics. Operating by measuring/calculating as well as by seeing/describing, each group sought the same ends: the identification of "racial elements." For all the differences in their legitimating arguments and use of media, they were eventually confronted with the same problem: They found discrepancies between the ideal "racial types" they thought they could pick out visually, the concrete prisoners they examined, and the 
calculated "types" they identified using mathematics ("Interpretation"). This discrepancy sheds light on the history of the methodology of physical anthropology in the prewar and wartime period. Even though these methods were fundamentally challenged by the experiences of "fieldwork" in the camps, they did not prevent the protagonists from exploiting their time there to launch careers and enhance prestige ("Conclusions").

\section{Project Planning}

German and Austrian POW camps during World War I offered scientists of the Central Powers (the German, Austro-Hungarian, and Ottoman Empires, and, after 1915, Bulgaria) attractive conditions for their research. The opposing political block consisted of a variety of nations and ethnic groups: Belgium; the nations of the Triple Entente: the UK, France, and Russia; peoples from the Asian part of the Russian Empire; and the African and Asian colonial troops of Britain and France. As Rudolf Martin (1864-1925), professor of anthropology in Munich, put it: "Because of our enemies' practice of gathering auxiliary troops from everywhere, representatives of the most diverse peoples have indeed come to Germany who would never have touched German soil under normal conditions." The camps allowed scientists to examine normally distant peoples as they might at a Völkerschau, ${ }^{2}$ with all the comforts of home. For the researchers, traveling through the POW camps seemed like inverted travel around the world; the camps served as a kind of exhibition of ethnic "types." The simultaneous presence of various different nationalities in the camps attracted above all researchers who did comparative studies: linguists, musicologists, sociologists, anthropologists, and ethnologists.

The structure of the camps seemed to preclude many of the problems which usually accompanied studies in the ethnographic field. Rudolf Pöch (1870-1921), associate professor of anthropology and ethnology in Vienna since 1913, remarked that:

The conditions artificially caused by the war are much more convenient for anthropological examinations than all other natural ones. All the preparations to find

1 Rudolf Martin, "Anthropologische Untersuchungen an Kriegsgefangenen," Die Umschau 19 (1915): 1017. The term "colored auxiliary troops" [farbige Hilfstruppen] was rather derogatory, clearly privileging the European soldiers' value, compared to the value of the colonial troops.

2 Völkerschauen, "ethnic shows," took place in Europe from the middle of the nineteenth century onward and consisted of groups of "foreign" (nonEuropean) people who had to represent their "culture" via songs, dances, rituals, and so forth. 
and assemble the persons to be measured are left out. The people are there, at our disposal. We do not need to sift through the material, since thanks to the military selection process the useless elements for the study of racial characteristics have already been eliminated. The examination can take place under the best possible circumstances; it is laboratory work, compared to that of a travelling researcher outside. $^{3}$

In the scientific laboratory exported to the camp and the imported ethnographic field, the test persons as well as the technical apparatus and scientific methods seemed utterly unproblematic, at least at first glance. But as the studies were carried out, the very definition of racial "types" proved to be troubled on many levels. These problems resulted, on the one hand, precisely from the specific conditions of the camp laboratories and, on the other hand, from the anthropological method itself.

In Austria, studies in POW camps were initiated by Pöch and the Viennese Anthropological Society. Body measurements, along with photographic, sound, and film recordings, were financed in large part by the Imperial Academy of Sciences in Vienna and carried out between the summer of 1915 and November 1918.

In contrast, much of the research in Germany was not launched so much by an academic discipline as by a medium - the phonograph or gramophone. During 1915, Professor Carl Stumpf (1848-1936, musicologist, psychologist, and founder of the Berlin Phonogram Archive) and the grammar school teacher Wilhelm Doegen (1877-1967, popularizer of gramophone records in language instruction) requested permission for a group of scientists to conduct linguistic and musicological research in German POW camps for a comparative archive. ${ }^{4}$ That November, the Königlich Preußisch-Phonographische Kommission [Royal Prussian Phonographic Commission] was established by the Prussian Ministry of Culture and completed more than 2,500 recordings by the end of $1918 .{ }^{5}$ Felix von Luschan (1854-1924, Royal Ethno-

3 Rudolf Pöch, "Anthropologische Studien an Kriegsgefangenen," Die Umschau 20 (1916): 989.

4 See also the article by Monique Scheer in this volume as well as Britta Lange, "Ein Archiv von Stimmen: Kriegsgefangene unter ethnografischer Beobachtung," in Original/Ton: Zur Mediengeschichte des O-Tons, vol. 34, Kommunikation audiovisuell, eds. Harun Maye, Cornelius Reiber, and Nikolaus Wegmann (Constance: Universitätsverlag Konstanz, 2007), 317-342.

5 See, for example, Kirsten Bayer and Jürgen Mahrenholz, "Stimmen der Völker'-Das Berliner Lautarchiv," in Theater der Natur und Kunst, eds. Horst Bredekamp, Jochen Brüning, and Cornelia Weber, vol. 2, Katalog: Wunderkammern des Wissens (Berlin: Henschel, 2000), 117-128; Susanne Ziegler, "Die akustischen Sammlungen: Historische Tondokumente im Phonogramm-Archiv und im Lautarchiv," in Theater der Natur und Kunst, 
logical Museum in Berlin, professor of anthropology and ethnology at the University of Berlin since 1911) was the Commission's ethnological consultant. He advised several young scientists-in particular his doctoral student Egon von Eickstedt (1892-1965) - on taking biometric measurements in the camps, but the German project remained much smaller in scope than that of Austria.

Pöch had also studied under Luschan, and the two maintained close contact, exchanging their experiences with the camp studies. With regard to methods, both invoked Martin's standard work Lehrbuch für Anthropologie in systematischer Darstellung [Systematic Manual of Anthropology], published in $1914 .^{6}$ To achieve reliable "racial diagnoses," Martin recommended "somatoscopic" observations of nonquantifiable characteristics, such as eye and nose shape and hair and eye color-qualities describable only qualitatively and in relative terms. Therefore, Martin and other anthropologists devised a fixed system of adjectives and number codes for such characteristics. Most of the book, however, was dedicated to the presentation of "somatometric" methods, making it a "real guide for techniques of physical measurements" 7 as late as the 1960s. The data gathered were interpreted using statistical analyses.

Martin's standardized catalogue of data-gathering methods and his techniques of measurement and calculation were all predicated on one fundamental assumption. In the 1830s, the Belgian astronomer Adolphe Quételet had discovered that the measured values of human physical characteristics were distributed at random around an average value as were his astronomical observations. This led him to conclude that the average represented an "average man" [homme moyen] from which real, existing people deviated in minor, but predictable, ways. As a consequence, this "average man" would conform to the (ideal) "type" of a human collective which could be defined statistically within anthropometrics and be visualized by the bell shape of the Gauss error distribution curve. ${ }^{8}$ Like many other anthropologists, Martin subscribed to Quételet's vision. He worked not only with measured values, but with indices (ratios of two values), referring mainly to the work of the French brain

vol. 1, Essays (Berlin: Henschel, 2000), 197-206. See also http://www.huberlin.de/lautarchiv (accessed February 15, 2010).

6 Rudolf Martin, Lehrbuch für Anthropologie in systematischer Darstellung: Mit besonderer Berücksichtigung der anthropologischen Methoden für Studierende, Ärzte und Forschungsreisende (Jena: Fischer, 1914), 7.

7 See Wilhelm E. Mühlmann, Geschichte der Anthropologie (Frankfurt a.M.: Athenäum, 1968), 100.

8 Adolphe Quételet, Anthropométrie, ou mesure des différentes facultés de I'homme (Brussels: Muquardt: 1870). 
researcher Paul Broca. ${ }^{9}$ To relate different characteristics and define their interdependency, he applied the British correlation analysis developed by Francis Galton and Karl Pearson. ${ }^{10}$

This mathematical approach suggested that human "racial elements" or "biological types" could be defined by interpreting the measured data. During the nineteenth century, "races" had been regarded as stable entities which could be definitively classified, ${ }^{11}$ but the emergence of genetics at the turn of the century had provoked a rethinking of existing "racial types." Eugen Fischer's research on the "Rehoboth bastards"-offspring of European colonists and local populations in South Africa-appeared to prove that inheritance of human morphological complexes conformed to Mendel's hypotheses about peas. ${ }^{12}$ It was not the "racial type" as a whole which was passed on, but only isolated traits, thus, the combination of two "races" would create not a new "race," but a "racial mixture." Physical anthropologists thus reasoned that it should be possible to deduce the postulated "original" races or "racial types," which no longer existed in their "pure" form in the present, from the existing "mixed" populations. They made it their task to disassemble the "racial elements" of the heterogeneous peoples of the present through measurements and a mathematical approach. The POW camps seemed ideal for this purpose, as they contained members of different ethnic groups that might be related.

\section{Realization}

For the camp studies, Pöch basically followed Martin's recommendations, adopting thirty-two required measurements from his manual ${ }^{13}$ (Figures 1 and 2). He preferred Luschan's Nasenschema [nose scheme], however, as “much

9 Paul Broca, Mémoires d'anthropologie, in 5 parts (Paris: Muquardt, 1871-1888). See Martin, Lehrbuch für Anthropologie, 63-66. Martin also referred explicitly to the work of Stanislaw von Poniatowski.

10 Ibid.

11 See, for example, the system of six "main races" and thirty "subraces" proclaimed by Joseph Deniker in Les races et les peuples de la terre (Paris: C. Reimer, 1900).

12 See Eugen Fischer, Die Rehoboter Bastards und das Bastardisierungsproblem beim Menschen (Jena: Fischer, 1913).

13 Pöch published four reports on his ongoing research in the POW camps in the Mitteilungen der Anthropologischen Gesellschaft in Wien [journal of the Anthropological Society of Vienna] (MAGW): Vol. 45 (1915): 219-235; Vol. 46 (1916): 108-131; Vol. 47 (1917): 77-100; Vol. 48 (1918): 146-161. He remarks in the first report (1915) on adopting Martin's recommendations on page 232. The form used to record the measurements is reproduced on pages 125 and 126 of the second report (1916). 


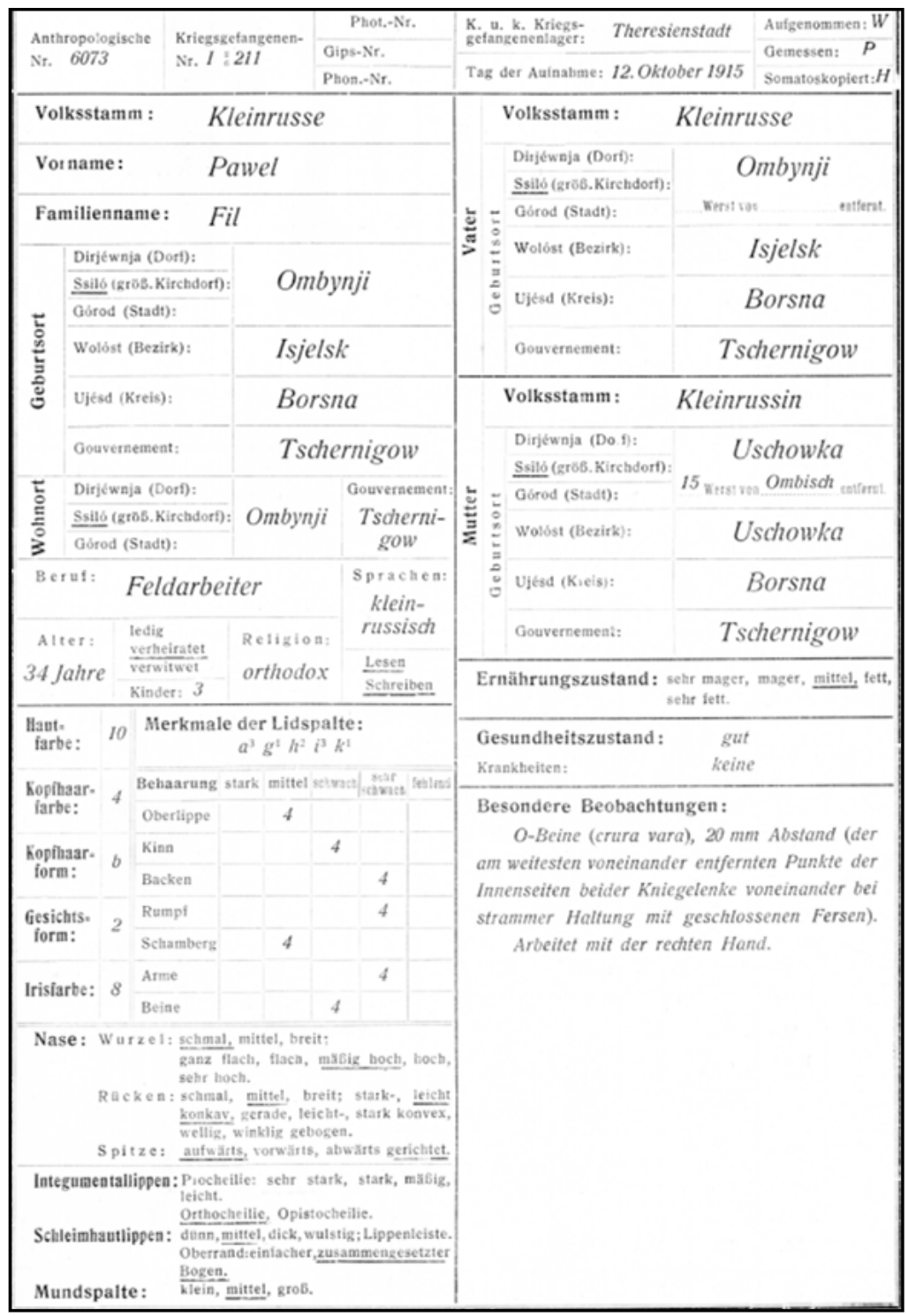

Figure 1. Form used by R. Pöch and his assistants for recording measurements taken on the POWs. Source: Pöch, "2. Bericht," 108-131. 


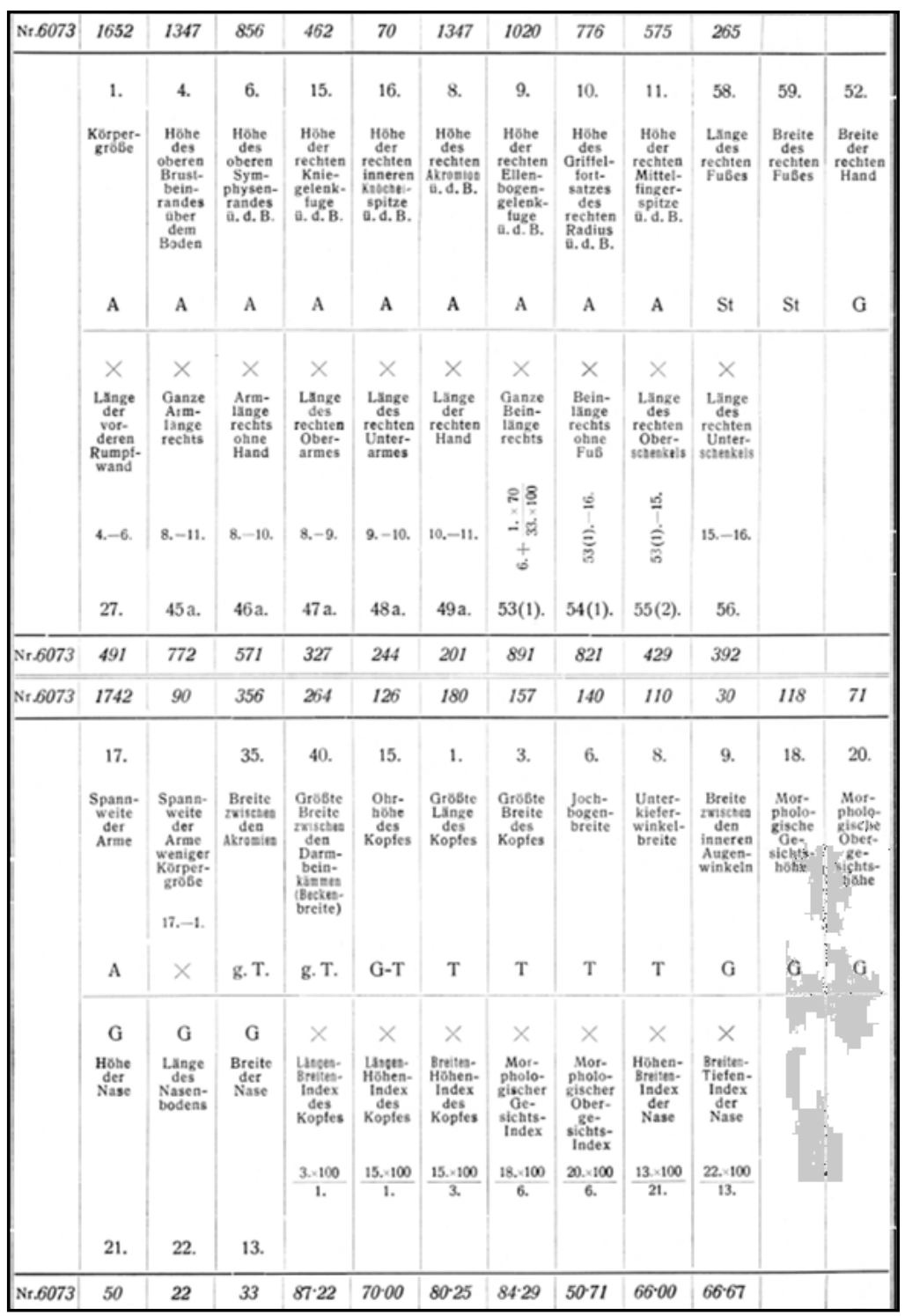

Figure 2. Form used by R. Pöch and his assistants for recording measurements taken on the POWs. Source: Pöch, "2. Bericht," 108-131. 
more convenient" than Martin's, ${ }^{14}$ along with the Haarfarbentafel [hair color chart] devised by Fischer. Pöch developed his own schemes for classifying the eyes and facial shape, which he also used in his lectures at the university. ${ }^{15}$ Because he was accountable to his financial backers, he published progress reports every year. The first report showed that, only a short time after beginning work in 1915, the Vienna-based anthropologists had already examined hundreds of prisoners. ${ }^{16}$

German anthropologists felt forced to react. Martin wrote to Luschan that it would be "truly sad" if the Germans could not afford "what Pöch accomplished in Austria." ${ }^{17}$ Luschan promoted a German project and asked, in the summer of 1915, for a sample of Pöch's data sheet. The Austrian professor confirmed that he would like "the analyses in Austria-Hungary and Germany to be realised in a standardised and complementary way." 18 The idea was for Luschan and Pöch to plan the simultaneous research conjointly, making their research results comparable and offering a standardized basis for statistical calculations to be performed after the war. ${ }^{19}$

Luschan obtained permission for his student Eickstedt to examine POWs in various German camps. Armed with the classic instruments of physical anthropology, the student numbered his subjects, noting prescribed measurements on the standardized forms. From January 1916 until February 1917, he traveled through sixteen German camps, applying his calipers to a total of 1,784 individuals whom he assigned to sixty-six "peoples." His identification of "racial types" came close to those Luschan had already identified by telediagnosis, based on descriptions provided in Eickstedt's letters.

Where Pöch's published reports in the Proceedings of the Academy of Sciences in Vienna and in the Journal of the Viennese Anthropological Society were objective in tone and even optimistic, Eickstedt's letters to Luschan seem fraught with doubt. One reason for the contrast is surely that Pöch's articles aimed to justify the support given him by both institutions and to secure

14 Postcard from Rudolf Pöch from the POW camp in Theresienstadt (Bohemia) to Felix von Luschan, 1 October 1915, Staatsbibliothek Berlin, Handschriftenabteilung [manuscripts], Nachlass [private papers] Felix von Luschan (quoted below as STBBNLL), correspondences with Pöch, p. 214.

15 Letter from R. Pöch to Luschan, 3 July 1916, STBBNLL, p. 228-229.

16 See Rudolf Pöch, "1. Bericht über die von der Wiener Anthropologischen Gesellschaft in den k.u.k. Kriegsgefangenenlagern veranlaßten Studien," MAGW 45 (1915): 45.

17 Letter from Rudolf Martin to Luschan, 16 April 1917, STBBNLL.

18 Postcard from R. Pöch in the POW camp in Reichenberg (Bohemia) to Luschan, 29 August 1915, STBBNLL, p. 210.

19 See letter from R. Pöch from the POW camp in Reichenberg to Luschan, 13 September 1915, STBBNLL, p. 212-213. 
future financing. Another was that his studies were arguably quite successful. He felt he was examining "racial groups" that could be delineated without serious inconsistencies. Eickstedt's diary-like correspondence with his adviser Luschan, on the other hand, was not meant for publication. Confronted with a much wider range of "peoples" than in the Austrian camps and, unlike Pöch, working alone, he reported not only difficulties in defining "racial types," but also in the most basic processes of data gathering.

Eickstedt's letters provide a rare close-up view of the manifold problems that scholars encountered when doing "fieldwork" in the POW camps. The camp-laboratory's supposed logistical advantage-access to diverse groups gathered conveniently on German soil-turned out to be the chief impediment to research. In contrast to the situation of scientists traveling to the home countries of their informants, the lack of the ethnographic field, of geographical, social, and cultural context, threw the prisoners' nationalities into question. Their ethnic identity, however, was the very basis for constructing groups for the purposes of comparative analysis. The camp scientists had to rely on affirmations of affiliation provided by subjects themselves, and they were apparently not always reliable, as Eickstedt's letters show: "Tomorrow at 9 a.m., we will check the validity of the nationality of 50 Tatars." ${ }^{20}$ In many cases, he was simply unable to verify ethnische Echtheit ${ }^{21}$ [ethnic authenticity] and had to content himself with affirmations instead of the hard facts provided by devices: "No. 728, a 29-year-old Kabyl from Tiziouzou (French communal state, Sardún Ghusín near Mukhamed, comes from the nearby village Beni Meádgar) has again reaffirmed that he is a very true Kabyl." 22 The questioning by the scientist thus allowed the more savvy prisoners to escape the measuring procedure ("many tried to chicken out by giving imprecise or obviously wrong information"). ${ }^{23}$

Anthropologists with field experience were well acquainted with such unruliness. Test persons would only rarely agree to undress and be touched by scientists or their instruments. In January 1916, for example, Eickstedt attempted to measure "Russian Jews" who "had little inclination for anthropology," as he reported to Luschan: They "try to get around my nice measurements in many

20 Letter from Egon von Eickstedt from the POW camp in Ohrdruf to Luschan, 28 February 1916, STBBNLL.

21 Expression used by Werner Michael Schwarz, Anthropologische Spektakel:Zur Schaustellung "exotischer" Menschen; Wien 1870-1910 (Vienna: Turia und Kant, 2001), 40-41.

22 Letter from Eickstedt from the POW camp in Darmstadt to Luschan, 20 May 1916, STBBNLL.

23 Postcard from Eickstedt from the POW camp in Ohrdruf to Luschan, 18 March 1916, STBBNLL. 
ways. I always have to corner them with tricks and cigarettes." ${ }^{24}$ When prisoners learned why they had been brought to the office, they "simply ran away."

Additional problems arising from the POW-camp setting included insufficient instruments, inadequate supplies, inappropriate spaces, poor lighting, and language barriers that forced anthropologists to work with interpreters. But some problems were immanent to the anthropological method itself. In January 1916, Eickstedt wrote to Luschan: "Why don't we measure the amplitude of the zygomatic bone?" ${ }^{26}$ He immediately received the order to proceed. ${ }^{27}$ His letters reveal many doubts:

I am measuring 14 men on an average day and have reached no. 315 today. There are around 12 Estonians and Latvians. I think I will be done next Thursday. However, I would really like to measure Moroccan, French, and English Jews. To compare the results should be most interesting. [...] Until now I have measured the amplitude of the hand while forming a fist. But it seems to me that the extended hand would provide reliable values. How should I proceed? The new measurements would be a little smaller and not comparable to the old ones. [...] There seems to be a relation between the size of the body and the ankle, but there are many exceptions. ${ }^{28}$

The methods were unsophisticated, especially when it came to their practical implementation. But they could not be modified in course of the investigations without reducing the comparability of the results.

At the same time, Eickstedt's reflections showed that it might have been necessary and reasonable to reconsider the methods. Pöch also thought so: He wrote to Luschan in April 1916 that, apart from gathering data, the point of the camp studies was to make "permanent changes and improvements in method and technique." ${ }^{29} \mathrm{He}$ and his assistant Josef Weninger took steps to optimize wartime data collection on an ongoing basis. Their innovations were aimed less at measurement procedures than at strategies of description and medial reproduction. Pöch improved the technique for making plaster head casts, publishing detailed instructions. ${ }^{30} \mathrm{He}$ added a third "norm" to anthro-

24 Letter from Eickstedt from the POW camp in Groß-Breesen near Guben to Luschan, 11/12 January 1916, STBBNLL.

25 Postcard from Eickstedt to Luschan, 13/14 January 1916, STBBNLL.

26 Letter from Eickstedt from the POW camp in Groß-Breesen to Luschan, 3 January 1916, STBBNLL.

27 See letter from Eickstedt from the POW camp in Groß-Breesen to Luschan, 6 January 1916, STBBNLL.

28 Letter from Eickstedt from the POW camp in Erfurt to Luschan, 4/5 February 1916, STBBNLL.

29 Postcard from R. Pöch from the POW camp in Hart near Amstetten to Luschan, 16 April 1916, STBBNLL, p. 246.

30 Rudolf Pöch, "3. Bericht über die in den k.u.k. Kriegsgefangenenlagern veranlaßten Studien," MAGW 47 (1917): 88-90. 


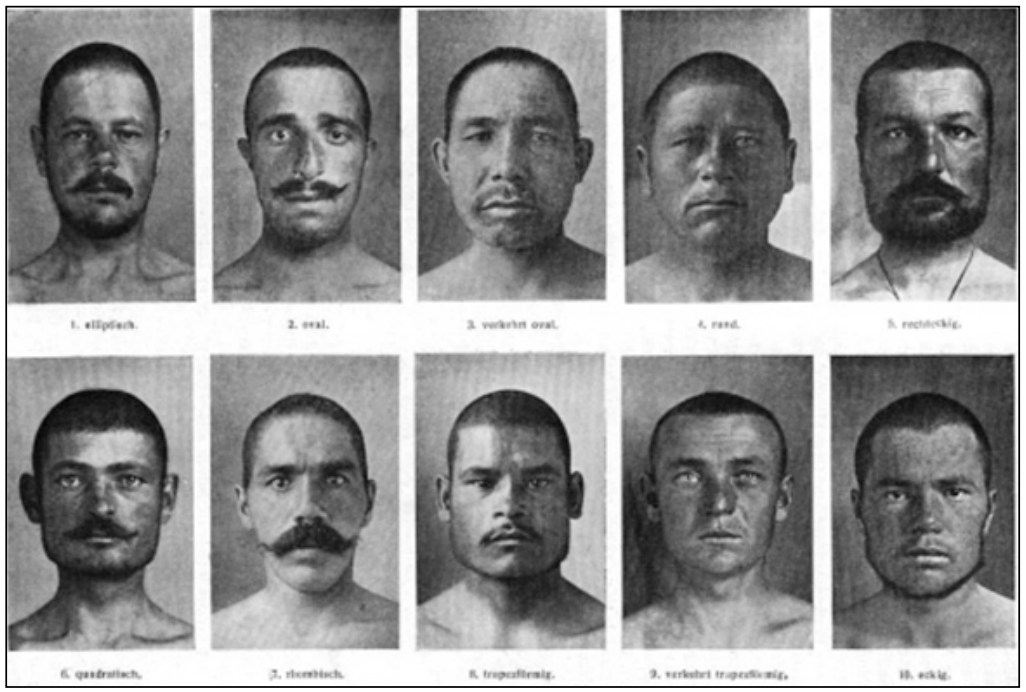

Figure 3. R. Pöch's table of "facial forms." Source: Pöch, "2. Bericht."

pological photography's usual two poses as per Alphonse Bertillon (en face and en profil), an Eindrittelseitenaufnahme [one-third side photo] in which the head was turned 30 degrees away from the frontal position to replace the frequently used "three-quarter profile photo." ${ }^{31}$ For photographs "in the three norms," the anthropologists at first used a modified Bertillon camera and later a new model constructed by the Viennese firm Moll. ${ }^{32}$ Pöch and Weninger also expanded criteria for describing the body, particularly the face, with "somatologic forms" that went beyond Martin, focusing particularly on the eye and the epicanthal fold (which was thought to reveal "Mongolian" ancestry) ${ }^{33}$ and developing a partitioned scheme for the nose. ${ }^{34}$ Still, the modifications did not violate Martin's framework, but merely improved techniques that went fundamentally unchallenged (Figures 3 and 4).

A prerequisite for the statistical analysis according to Martin was the existence of a collective, permitting a random sample capable of rendering meaningful results. To Pöch's and Martin's mind, the prison camp was such an ideal research site precisely because it offered these conditions. But the construction

31 Ibid. 85-88.

32 Idem, "4. Bericht über die in den k.u.k. Kriegsgefangenenlagern veranlaßten Studien," MAGW 48 (1918): 150-157.

33 Idem, "2. Bericht über die in den k.u.k. Kriegsgefangenenlagern veranlaßten Studien," MAGW 46 (1916): 115-127. For further modifications of the somatologic form, see idem, "4. Bericht," 157-161.

34 Idem, "3. Bericht," 83. 


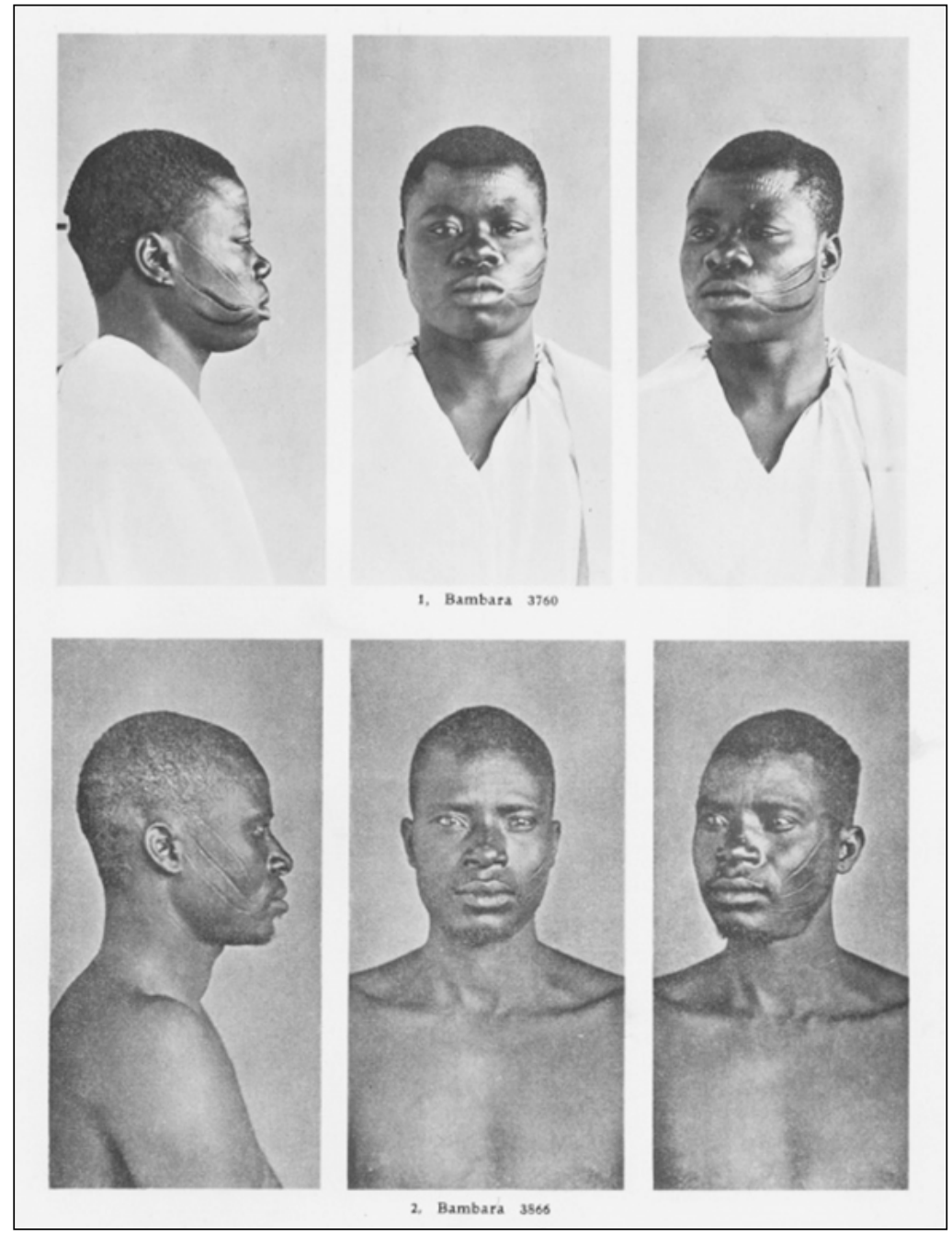

Figure 4. Photographs of West Africans "in the three norms" developed by R. Pöch. Source: Weninger, Eine morphologisch-anthropologische Studie.

of the collectives necessary for statistical studies turned out to be the most daunting problem facing the camp scientist. As they themselves had to admit, the prisoners were all men who had been judged large and strong enough for military service. Without women, children, and invalids, obviously no group present in the camps was actually representative of the population of any nation or region. The so-called "material" for study was not randomly selected at all, but selected according to the criteria of the military and then again according to the interests of the scientists. 
Once the ethnic collectives had been defined, the next task was ostensibly to "uncover" their "racial elements." Where these were already known beforehand, researchers had merely to identify them in particular prisoners, Pöch explained. But even where "elements" remained to be defined, researchers should "already have in mind an idea of the different racial types within a certain group while gathering material; then one would be able to take those types into account while selecting and describing the subjects." Pöch suggested that researchers select subjects for group assignment according to the frequency and similarity of their "characteristics."

Apart from giving a feeling of the togetherness of a self-contained type, the repetition of a certain image will allow for the definitive fixation of a type. The concluding judgement about the composition of a population has to be made only at the end of the examinations, but I recommend beginning with at least a provisional classification of types, because the observer will better recognise the main types at the beginning of his research. The longer one deals with a group of people, the better the recognition of single characteristics will get; but at the same time the unprejudiced registration of the important will suffer! I thus recommend that researchers classify the main types right on the first day of examining a new group. Of course, the indices have to be calculated at the same time, as one needs the measured values as well as the described characteristics to define a type. The ceaseless control and critique during the following examinations will often invalidate the types initially proposed. We have followed the method to note the belonging to a certain type as it seemed at first glance on the measuring sheet. This note has to be checked later on, and the classification of types is only definitive when all the material has been examined. ${ }^{35}$

Pöch recommended identifying "types" with an initial impartial scan, then calculating their indices and comparing the results with what had been seena dialectical procedure in which "anthropological seeing" or even "feeling" comes before, and ranks above, measurement. It is obvious that Pöch's results, despite his protestations of positivism, would be strongly influenced by preconceptions. For him, calculation acquired an objectifying function dependent on the visual focus, the role of mathematics being, above all, to confirm what had been seen. Eickstedt, in contrast, strove to retain his focus on each ethnic group as a whole, working primarily with the measurements he had taken. The two approaches to the practice of physical anthropology both employed mathematics and vision, but in reverse order and with varying emphasis. The problem they faced remained the same: a (more or less pronounced) discrepancy between the concrete individuals in the camps, the ideal "racial types" often visualized by selected photographs, and the calculated "types" that resulted from applying statistics.

35 Idem, "2. Bericht," 79. 


\section{Interpretation}

The first work emerging from the Viennese researches in the POW camps to appear in book form was Eine morphologisch-anthropologische Studie: Durchgeführt an 100 westafrikanischen Negern [A Morphological-Anthropological Study Conducted on 100 West African Negroes], published by Weninger in $1927^{36}$ (Figures 5 and 6). Pöch's former assistant grouped his one hundred subjects according to their "tribes." For each group and each physical characteristic, he provided a table with the average, standard deviation, and variation coefficient, as well as the probable error of all three, along with the range of variation, that is, the minimum, maximum, and the span between the two. ${ }^{37}$ His operations reduced the procedures suggested by Martin to a more generally comprehensible minimum. Weninger's graphs were confined to frequency distributions: They showed the curve resulting from measured values or indices and the number of people they corresponded to. All display clear-cut peaks near the average, slightly resembling the curve of a normal distribution and therefore seeming to indicate homogeneous groups (Figures 7 and 8).

Weninger considered measurements merely a framework, giving much more attention to the "observation" of "somatologic" characteristics. In 1924, he and Hella Pöch had published their Leitlinien zur Beobachtung der somatischen Merkmale des Kopfes und Gesichtes am Menschen [Guidelines for the Observation of Somatic Characteristics of the Human Head and Face], based on the reports published by Rudolf Pöch during the war. ${ }^{38}$ They legitimated the approach by reference to the insights of experimental genetics: "If a form is not inherited completely, if the characteristics composing this form are inherited separately, we have to begin to decompose the forms we see into their discrete characteristics." ${ }^{39}$ Features, such as the folds of the eyelid, were

36 Josef Weninger, Eine morphologisch-anthropologische Studie: Durchgeführt an 100 westafrikanischen Negern, als Beitrag zur Anthropologie von Afrika, (= Rudolf Pöchs Nachlass, Serie A: Physische Anthropologie, Band 1) (Vienna: Verlag der Anthropologischen Gesellschaft in Wien, 1927). As Austrian POW camps contained almost exclusively citizens of the Russian Empire, Pöch and Weninger traveled to Berlin in 1917, invited by Luschan, to do research on Africans and Asians in the camps of Wünsdorf and Zossen. Pöch died in 1921 and did not publish anything about the camp studies beyond his progress reports. But he willed half of his legal estate to the Viennese Academy of Science to finance publications by his students based on his scientific legacy.

37 Weninger, Eine morphologisch-anthropologische Studie, 15.

38 Hella Pöch and Joseph Weninger, "Leitlinien zur Beobachtung der somatischen Merkmale des Kopfes und Gesichtes am Menschen," MAGW 54, no. 6 (1924): 232-270.

39 Ibid. 232. 


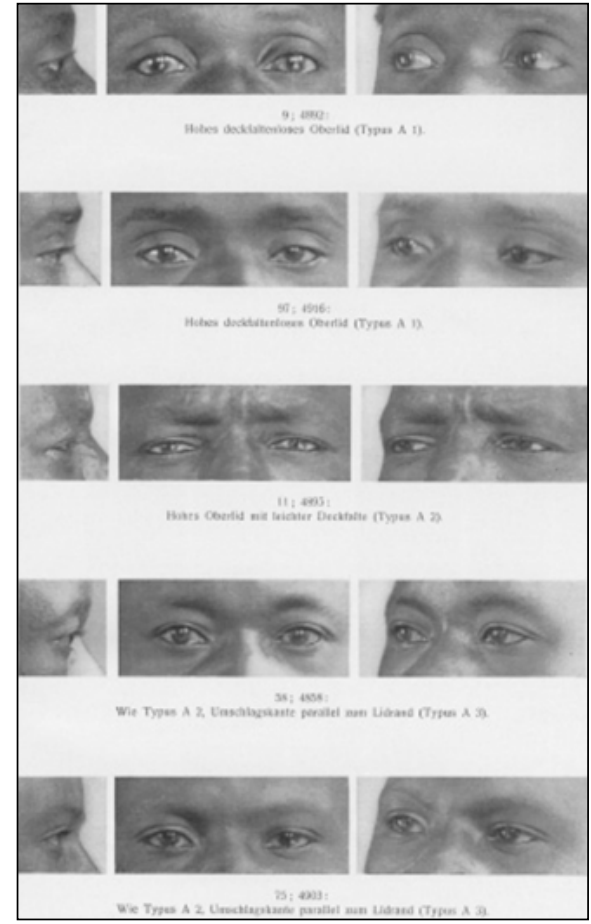

Figure 5. Types of eyes according to Weninger. Source:Weninger, Eine morphologisch-anthropologische Studie.

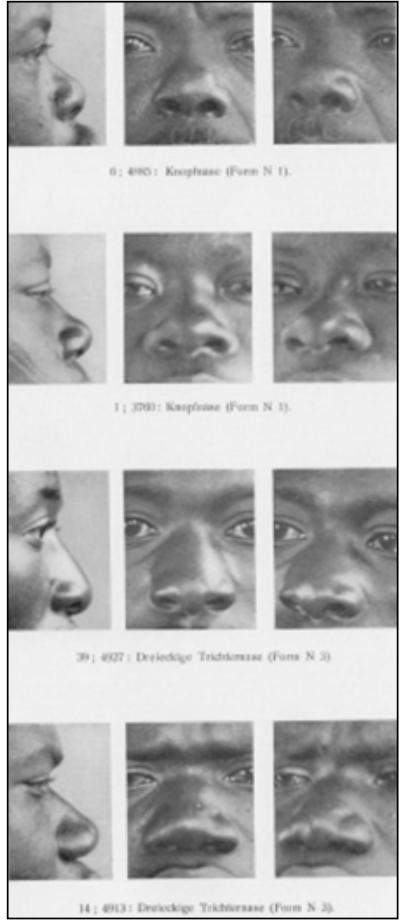

Figure 6. Types of noses according to Weninger. Source: Weninger, Eine morphologischanthropologische Studie.

\begin{tabular}{|c|c|c|c|c|c|c|}
\hline \multicolumn{7}{|c|}{ f) Der morphologische Obergesiditsindex. } \\
\hline Stamm & n & Variationsbreite & Spannung & $M \pm E(M)$ & $3 \pm \mathrm{E}(0)$ & $v \pm E(v)$ \\
\hline Bambara & 27 & $4245(4286)-(54 \cdot 62) 5938$ & 1693 & $4885 \pm 052$ & $403 \pm 037$ & $825 \pm 0.75$ \\
\hline Tukulor & 16 & $43-17(45-95)-(54-23) 5462$ & $11 \cdot 45$ & $4912 \pm 050$ & $300 \pm 036$ & $611 \pm 072$ \\
\hline Malinke & 11 & $37 \cdot 59(44 \cdot 85)-(52-59) 57 \cdot 67$ & 2008 & $4900 \pm 097$ & $4 \cdot 78 \pm 068$ & $975 \pm 1 \cdot 40$ \\
\hline Wolof & 10 & $4621(47-33)-(5074) 54 \cdot 48$ & 827 & $4930 \pm 045$ & $2 \cdot 08 \pm 0 \cdot 31$ & $4 \cdot 22 \pm 063$ \\
\hline Susu & 6 & $44.85(46 \cdot 10)-(53 \cdot 44) 56.82$ & $11 \cdot 97$ & $5008 \pm 1 \cdot 12$ & $409 \pm 080$ & $8 \cdot 17 \pm 1.59$ \\
\hline Sammelgruppe & 30 & $37.59(39-04)-(54 \cdot 48) 5565$ & 1806 & $4787 \pm 0-53$ & $4 \cdot 28 \pm 037$ & $894 \pm 078$ \\
\hline Gesamtmaterial & 100 & $37.59(3759)-(5767) 59 \cdot 38$ & 2179 & $4870 \pm 0.27$ & $396 \pm 019$ & $813 \pm 0.39$ \\
\hline
\end{tabular}

Figure 7. The morphological index of the upper face. Source: Weninger, Eine morphologisch-anthropologische Studie. 


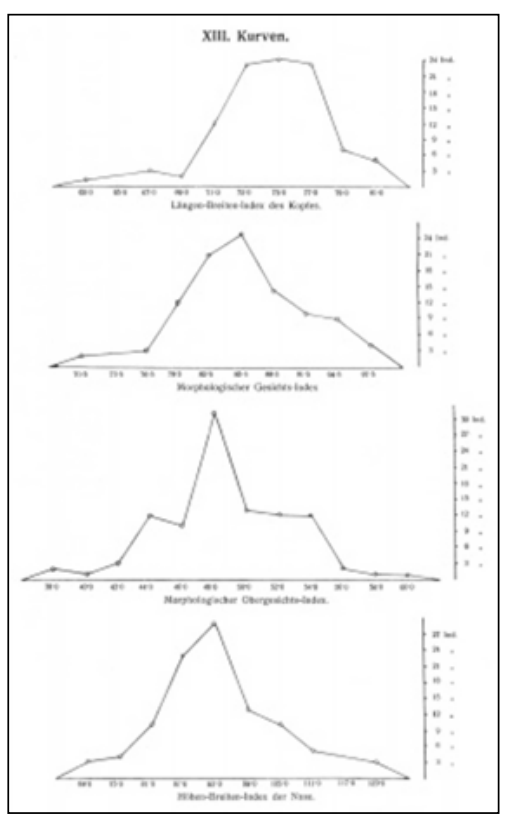

Figure 8. Curves on various indices. Source: Weninger, Eine morphologischanthropologische Studie. categorized with standardized qualifying attributes. Weninger grouped people who displayed the same attributes into Sammelgruppen [collective groups] consisting of several ethnic groups. Only then, within the "collective group," did Weninger apply mathematical methods to obtain average height, for instance. The results were related back to the ethnic groups through percentages.

For such a procedure based on "anthropological" or "morphological seeing"-in contrast to measurement-photographic material turned out to be of key importance: "We were able to check every single morphological appearance against the carefully produced photographs; the well-made photos even drew our attention to many important details." According to Weninger, the photographs permitted "retroactive corrections and even some new observations." ${ }^{40}$ Pictures were deemed a genuine part of "anthropological seeing" and thus preceded mathematical operations.

Eickstedt limited his description of morphological characteristics (so-called "observations") to eye, hair, and skin color, beard shape, and the grip strength of the hand. He began his analysis of the camp data in the summer of 1919, submitting his dissertation in February 1920. His thesis supervisor, Luschan, arranged for publication of the work in the Anthropological Society's journal, Zeitschrift für Ethnologie, in 1921. ${ }^{41}$

In the printed version, Eickstedt explained that he had examined seventy-six Sikhs from the eastern Punjab in the POW camp of Wünsdorf, near Berlin. He took forty-five measurements per subject and calculated twenty-two bodily and nine head indices for each, deviating from Martin's recommendations only trivially. For example, he was constantly bothered by the height of the

40 Weninger, Eine morphologisch-anthropologische Studie, 17. As the photographs were black and white, they could not serve to identify colors.

41 Egon von Eickstedt, "Rassenelemente der Sikh," Zeitschrift für Ethnologie 52 (1920/21): 317-394. 
ear in relation to the head, ${ }^{42}$ eventually deciding to abandon this "difficult and unreliable measurement completely." ${ }^{43}$ His work aimed at understanding Biotypen or "racial elements" as well as Typengruppen and Phänotypen. ${ }^{44} \mathrm{He}$ incorporated statistics to make his data tell a story. While continuing to use Martin's models, he confidentially told Luschan that his

respect for M[artin]'s mathematics has diminished more and more. At least at some points, he himself did not understand what he was writing. Only in this way can one explain his contradictions and errors and, above all, the fact that he provides dead formulas but nothing to make them understandable. In this way, it is totally impossible to achieve results.

According to Eickstedt, the real problem lay not in the methods, but in Martin's far too voluminous explanation. ${ }^{45}$ The calculations, reported Eickstedt, were "all time-consuming and time-killing," ${ }^{\prime 6}$ and the corresponding graphs merely sowed confusion.

Eickstedt had initially assumed a single "racial type" for his Sikh subjects. A few weeks later, after some punishing mathematics, he confessed: "I dropped my initial idea that the Sikhs could be a homogeneous group. The curves seemed to show two groups. But having provisionally worked on them, I consider three groups most probable." ${ }^{47}$

The source of his uncertainty was the "recurrent peaks very close to each other" in his graphs. Presuming he would find a bell curve, Eickstedt guessed that the "occasional (slight) lopsidedness and the amplitudes of the peaks of simplified curves" indicated "heterogeneous material," that is, more than one "racial element." But, as he admitted himself, his difficulties also arose from the graphic visualization-for example, from the question "of whether the intervals had been chosen correctly." ${ }^{48}$ His doubts referred to a graph that he called the Variationspolygon (Figure 9). Because he used so few points per interval, the probable error

42 Letter from Eickstedt to Luschan, 3 January 1916, STBBNLL.

43 Eickstedt, "Rassenelemente der Sikh," 328.

44 Ibid., 340. Somatic groups: "racial elements" for Eickstedt were synonyms for "biotypes" [Biotypen], "genotypic entities" [genotypische Einheiten], and the "stable complex of dispositions" [stabiler Anlagenkomplex]; "groups of types" [Typengruppen] were synonyms to "phenotypes" [Phänotypen], "genotypic multiplicities" [genotypische Vielheiten] and the "unstable complex of dispositions" [labiler Anlagenkomplex]. In addition, he considered the possible existence of "external single types" [fremde Einzeltypen]. See ibid., 340-341.

45 Letter from Eickstedt to Luschan, 26 August 1919, STBBNLL.

46 Postcard from Eickstedt to Luschan, 6 August 1919, STBBNLL.

47 Letter from Eickstedt to Luscan, 26 August 1919, STBBNLL.

48 Letter from Eickstedt to Luschan, 29 June 1919, STBBNLL. 


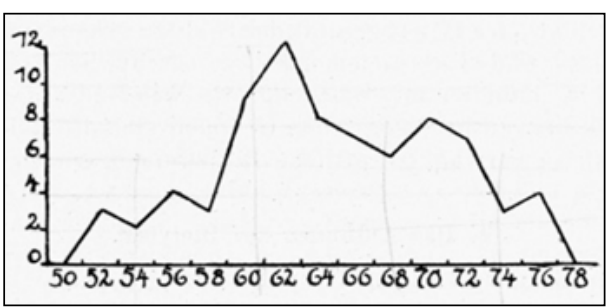

Figure 9. Variational polygon of he nasal index. Source: Eickstedt, "Rassenelemente der Sikh." of his curve rose to more than 50 percent. $^{49} \mathrm{He}$ was well aware that his strategy could produce "a false multi-peakedness" [eine falsche Mehrgipfligkeit]. ${ }^{50}$ To obtain meaningful results, he would have to have measured at least one hundred individuals, which he claimed was impossible under the circumstances.

The ambiguous compromise that the anthropologist had made by applying sensitive statistical analysis to a small sample size accommodated the practical and administrative potential of the measurements, but produced only limited results. The aim was an anthropology typology, but the mathematical approach selected did not seem to fit. Consequently, all his graphs occasioned similar troubles: "They all show a similar (not identical) curve with two very close peaks, comparable to the nose index and the head index of my people." ${ }^{1}$ Eickstedt nevertheless supposed that his results did not show a false, but a genuine, multipeakedness-an expression of the complex situation of the Sikh population. He asserted that other strategies, such as geographical analyses, would be necessary to clarify whether they were a heterogeneous population. ${ }^{52}$

He therefore began to correlate selected measurements according to British techniques of correlation analysis. Korrelationstabellen registered, for example, height and the nose index by listing the number of relevant subjects in a coordinate system (Figure 10). In the graph that resulted, he tried to find clusters (i.e., "types"), which he marked by circling. To confirm their accuracy, he would have been obligated to construct and compare multiple correlation charts. Instead, he queried the influence of geographical criteria ${ }^{53}$ and, as proof, correlated bodily indices with regions. He claimed that the geographische Kombinationstafeln [geographical combination boards], which permitted the "analysis of a mixed population based on their geographic distribution" constituted "his" method $^{54}$ (Figure 11). They served to explain the "genuine multipeakedness" of his graphs and the lack of a bell-shaped curve. In the end, his observations and

49 He divided the nose index of the Sikhs into twenty-five intervals to distribute seventy-six measuring points. The probable error was $1: \sqrt{76}$.

50 See Eickstedt, "Rassenelemente der Sikh," 375.

51 Letter from Eickstedt to Luschan, 22 July 1919, STBBNLL.

52 See Eickstedt, "Rassenelemente der Sikh," 376.

53 Ibid., 348.

54 lbid., 367. 


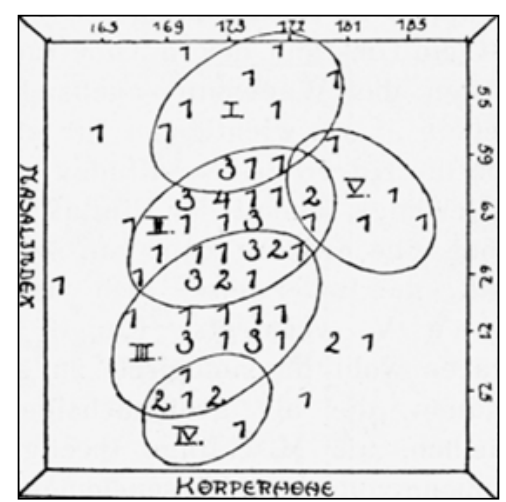

Figure 10. Correlation table for the nasal index with the body height. Source: Eickstedt, "Rassenelemente der Sikh."

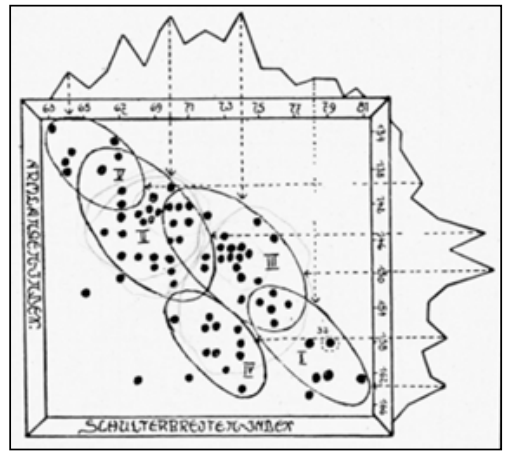

Figure 11. Combination table for the index of shoulder width and of arm length. Source: Eickstedt, "Rassenelemente der Sikh."

graphs suggested to him that the Sikhs were a heterogeneous population with two "racial elements" or Biotypen and three smaller "type groups" or Phänotypen, two of them closely associated with the "racial elements."

Statistical analysis had therefore compelled Eickstedt to revise his initial idea of a homogenous Sikh population. Mathematics had put forward what had not or could not have been seen before. That is to say, the "types" identified by mathematical means failed to match the "types" Eickstedt had seen. Had they coincided, his approach to the camps would have been tautological. ${ }^{56}$ But patently circular reasoning would have precluded the possibility of finding "racial elements" previously unknown to science-an aim he consciously pursued. Eickstedt did establish provisional "racial elements" by visual means, taking photographs of what he thought to be typical Sikhs of the eastern Punjab. But he was unable to match these "types" that were identified before the application of mathematics to the "types" which he later calculated for his dissertation, at least to some extent. The discrepancy derived from systematic errors using statistics on material that was not random, much too small, and clumsily handled. Furthermore, given the assumption of the ubiquity of racial "mixing," "racial elements" in their pure form could not have existed as phenotypes in reality in any case.

55 Ibid., 366.

56 Margit Berner has noted this tautology. See, for example, idem, "Forschungs'Material' Kriegsgefangene: Die Massenuntersuchungen der Wiener Anthropologen an gefangenen Soldaten 1915-1918," in Vorreiter der Vernichtung? Eugenik, Rassenhygiene und Euthanansie in der österreichischen Diskussion vor 1938 (= Geschichte der NS-Euthanasie in Wien, Teil III), eds. Heinz Eberhard Gabriel and Wolfgang Neugebauer (Vienna: Böhlau, 2005), 174. 
After the war, Eickstedt could not check his results on the prisoners he had measured. Because of the high cost of the procedure, he had not even photographed all his subjects. Where Pöch had aimed for a comprehensive visual archive of "foreign peoples," Eickstedt used the camera only to document selected individuals and to keep Luschan informed about his research. In 1919, he reported retrospectively: "I photographed around fifteen Sikhs. I tried to determine the average type." He added with delight that the "average type" hardly differed from drawings of Sikhs done by the Jewish artist Hermann Struck (1876-1944) that had been published in 1916.57

Beginning in 1915, Struck had planned "to craft a collection of lithographs and etchings which represents different types of our prisoners," wishing to make anthropological concerns relevant to its realization. ${ }^{58}$ When Luschan agreed to write an introduction, ${ }^{59}$ Struck assured him that he would remove drawings that Luschan did not deem appropriate. ${ }^{60}$ Luschan's authority grew as the project progressed. He not only intervened in the selection of lithographs, but in the drawings themselves, requesting specific changes. The artist responded to one of his letters:

Your remarks concerning the Negroid type were completely correct, and I immediately changed his hairdo. Now he has very nice curly Negro hair, and I think you will like him. I also enlarged the skull and the ear of a Russian that you rejected some time ago. ${ }^{61}$

Luschan was not content with the realities or interpretations of realities offered by Struck. He was determined to produce clear-cut "types." Unlike photography, the medium of drawing was highly amenable to such a project. About the pictures that were finally published, even Martin had to admit that "the overall impression emerges more clearly than with most photography." 62

Eickstedt thought the "type groups" of the Sikhs were better represented in Struck's drawings than in his own photographs, which he had taken "years before identifying the racial elements." His photographs "indicated only the direction in which we have to look for the characteristics and the outer appear-

57 Letter from Eickstedt to Luschan, 1/3 August 1919, STBBNLL.

58 Letter from Hermann Struck to Luschan, 25 May 1915, STBBNLL. See also the article by Margaret Olin in this volume.

59 Hermann Struck, Kriegsgefangene: Ein Beitrag zur Völkerkunde im Weltkriege; Hundert Steinzeichnungen, with a foreword by Prof. Dr. F. von Luschan (Berlin: Reimer, 1916). Luschan's text was illustrated by sixty photographs labeled "racial images" that were to supplement the drawings by Struck.

60 Letter from Struck to Luschan, 25 January 1916, STBBNLL.

61 Letter from Struck to Luschan, 14 March 1916, STBBNLL.

62 Letter from Rudolf Martin to Luschan, 16 April 1917, STBBNLL. 


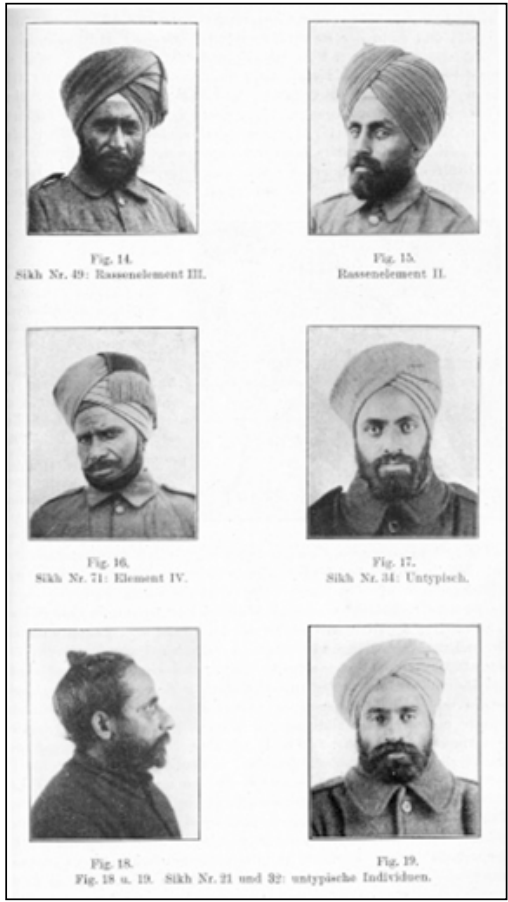

Figure 12. Six Sikh POWs; photographs by Egon von Eickstedt. Source: Eickstedt, "Rassenelemente der Sikh."

ance of the discrete elements." ${ }^{3}$ In 1919, he wrote to Luschan that his three main "types" of Sikhs had been "rendered perfectly" by Struck, "who as an artist appreciates the extreme." He also noted that:

He must have liked the broad-nosed Sikhs. [...] I have just noticed that Struck's pictures show the broad noses above all for Thakurn-which is correct. Couldn't I use one of his beautiful heads for my work $?^{65}$

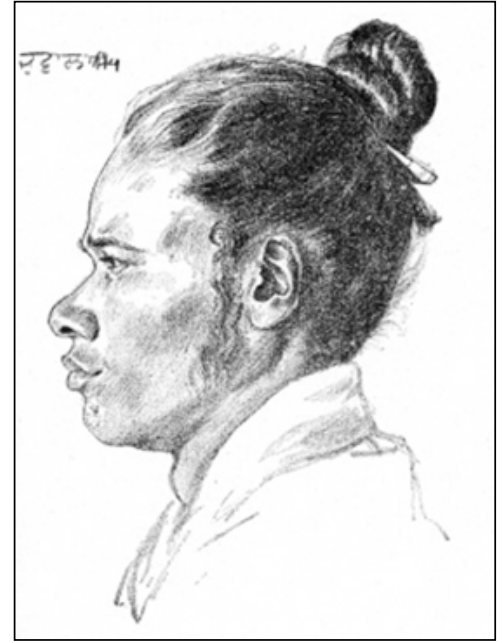

Figure 13. Sikh No. 73: [Racial] element IV. Source: Eickstedt, "Rassenelemente der Sikh."

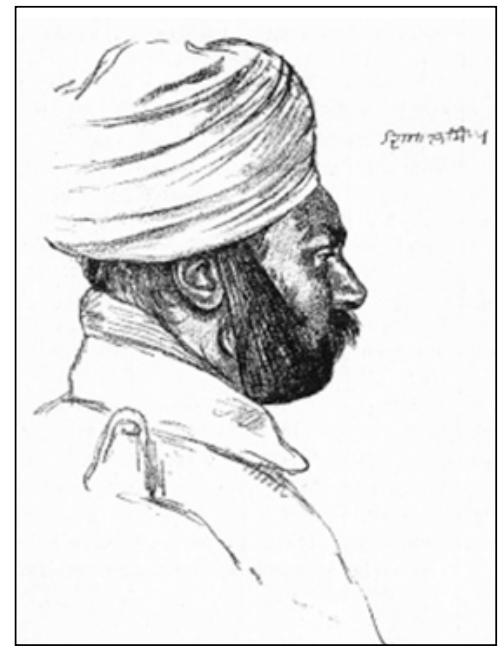

Figure 14. Sikh No. 46: [Racial] element III. Source: Eickstedt, "Rassenelemente der Sikh."

63 Eickstedt, "Rassenelemente der Sikh," 355.

64 Letter from Eickstedt to Luschan, 26 August 1919, STBBNLL.

65 Letter from Eickstedt to Luschan, 1/3 August 1919, STBBNLL. 


\section{Abhandlungen und Vorträge.}

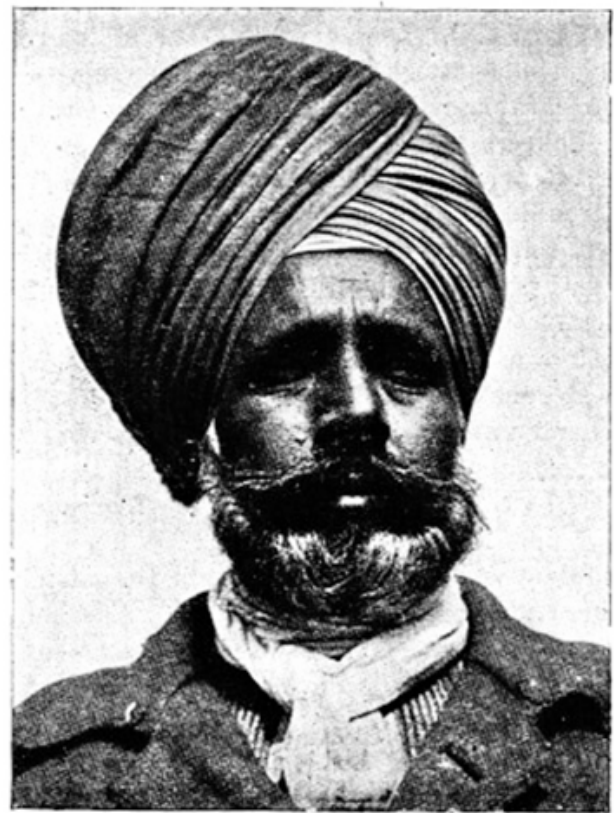

Fig. ${ }^{1}$ ). Sikh Nr. 25: Rassenelement II.

\section{Rassenelemente der Sikh.}

Mit einem Anhang über biometrische Methoden.

$$
\text { Von }
$$

Dr. Egon v. Eickstedt,

Assistent am geographischen Insti ut Freiburg i. B.

\section{I $\mathrm{n}$ h a $1 \mathrm{t}$ :}

1. Das Punjab in anthropogeographischer Beziehung . . . . . . . . . . 815

2. Vókerbewegungen in Nordwest-ndien und die Stellung der Jat Sikh * *. . . . 320

3 Die Aufarbeitung des Materials . . . . . . . . . . . . . . . . 3

4. Das Auffinden der Biotypen:

a) somatische Kombinationstafeln . . . . . . . . . . . . . . . . 39

b) geographische Kombinationstafeln $\ldots . .347$

c) Beschreibung der Elemente. . . . . . . . . . . . . . . . . . 355

5. Die Herkunft der Rassenelemente und Typengruppen. . . . . . . . . . . . . . 359

6. Zusammenfassung der Ergebnisse. . . . . . . . . . 366 A $\mathrm{n}$ h a $\mathrm{ng}$ :

1. Bemerkungen zu biometrischen und graphischen Methoden . . . . . . . 368

2. Literaturverzeichnis. .377

3. Personalien, Individualmaíse und Indices

3) Mit freundlicher Erlaubnis von Verfasser und Verleger reproduziert aus: O. Stiehl, Unsere Feinde, Verlag Holfmann, Stuttgart.

Zeitschrift für Etbnologie. Jabrgang 1920/21. Heft 4/5

22

Figure 15. Sikh No. 25: [Racial] element Il; photograph by Otto Stiehl, titel page of Eickstedt's thesis. Source: Eickstedt, "Rassenelemente der Sikh." 
In the end, Eickstedt's publication on Sikhs included six of his own photographs (Figure 12). Only three of them were identified with the "racial types," while the other three were labeled "untypical." Two drawings by Struck illustrated one "typical" Sikh and one who was "not totally typical," but represented two "racial elements" (Figures 13 and 14).

A third "racial element" was represented by a Sikh whom Eickstedt had measured in the camp, but who was illustrated by a photograph from the 1916 publication Unsere Feinde [Our Enemies] by the camp Commandant, Otto Stiehl ${ }^{66}$ (Figure 15). Stiehl's booklet included photographs of ninety-six "striking heads from German POW camps." His work enjoyed a positive reception by anthropologists. Although they found that he had not followed the norms of anthropological photography, "he had chosen his types with a very good eye." ${ }^{67}$ Reviewers granted the nonanthropologist, with his naïve gaze, as "good" an eye for types as a professional.

The success of Stiehl's photographs and Struck's drawings indicate both the imprecision of "anthropological seeing" and the ability of drawings to heighten "typical" traits. An anachronistic medium in the era of photography, drawings permitted easy simulation of "types." Photographs showed people, not hypotheses, therefore, photographs fulfilling anthropological ideals were scarce. ${ }^{68}$ In 1922, even the self-styled racial authority H. F. K. Günther (who later acquired the notorious nickname of "Rassengünther") asked readers of his third edition of Rassenkunde des deutschen Volkes [Racial Studies of the German People] "to send appropriate pictures to the publisher, pictures that provide good illustrations of racially pure or almost racially pure people."69

\section{Conclusions}

The differences between the findings of German and Austrian physical anthropologists looking for "racial types" or "racial elements" in POW camps did not stem from differing scholarly backgrounds, differences in "national schools," or because they worked with different "material"-Russian peoples in the Austro-Hungarian camps as opposed to peoples from the "rest of the world" in German camps. Rather, I have argued here that problems emerged

66 Otto Stiehl, Unsere Feinde: 96 Charakterköpfe aus deutschen Kriegsgefangenenlagern (Stuttgart: Hoffman, 1916).

67 See Rudolf Pöch, review of "Unsere Feinde" by Otto Stiehl, MAGW 47 (1917): 122.

68 See, for example, a copy of a letter from von Luschan to von Eickstedt, 19 November 1919, STBBNLL.

69 Hans Friedrich Karl Günther, Rassenkunde des deutschen Volkes, 3rd ed. (Munich: Lehmann, 1923), 3 (emphasis in original). 
from the methods of physical anthropology itself-the inherent disagreement between statistical and visual "data." Pöch solved the problem through visual preselection of individuals for measurement, fixing the data so that the math would support the visual evidence. Eickstedt tried to surmount the problem by using drawings to simulate "types" whose idealized visions existed only in the interplay between his statistical methods and his imagination.

As the snags in execution and interpretation show, the POW-camp studies were not the well-oiled anthropological machine that investigators had hoped for. They occasioned numerous problems, caused, on the one hand, by historical conditions and, on the other, by their own methods, with each complex of problems exacerbating the other. This could have led the researchers to conclude that it was necessary to abandon preconceptions, from the meaning of the material to the methods of physical anthropology. They had assumed from the outset that the original "racial elements" could not be found in their "pure" form and that the "original racial type" could only be taken as an ideal. So why did physical anthropologists not revise their methods? Possibly, because they could convince themselves that the methods were not the problem.

One ready excuse was a simple practical issue: Despite initial assertions, the camps did not provide access to large numbers of test persons within clearly defined collectives. Eickstedt resorted to studying a small group defined by religious and geographic criteria. But even Pöch and his assistants, looking at the peoples of Russia, could not find sufficient candidates from any single ethnic group: Meaningful results would have required at least one thousand test persons.

Another way of getting around their failure was in the integration of the problems into the anthropological method through the construction of "approximations." As Eickstedt stated, his results were only "approximations" of the original "racial elements." In his words, they should "only indicate the direction in which we have to look for the characteristics and the outer appearance of the discrete elements." The notion of approximation-elaborated philosophically and mathematically in the Kollektivmaßlehre [theory of collective measurements] of Gustav Theodor Fechner as a tool for physical anthropologists ${ }^{70}$ - did not define the distance from the ideal or original "type" precisely. It left an indeterminate space between concrete results and perfection. The gap could only be bridged by a similarly arbitrary step: a simulation, such as a drawing, for example.

Other, and perhaps the most effective, arguments favoring the further pursuit of physical anthropological methods concerned not content, but strat-

70 Concerning the "Kollektivmaßlehre" see, for example, Michael Heidelberger, Die innere Seite der Natur: Gustav Theodor Fechners wissenschaftlich-philosophische Weltauffassung (Frankfurt a. M.: Klostermann, 1993), 323-385. 
egy - the conquest and defense of academic redoubts. Eickstedt, a clear antagonist of the biogenetics of Fischer, never distanced himself from Martin's methods of applied statistics in physical anthropology, despite his bitter lamentations from the camps. In the 1930s, he even broadened the concept, insisting that physical types were linked to spiritual traits. He continued to employ the methods of physical anthropology, along with geographical criteria, while holding the chair for anthropology at the University of Breslau from 1933 onward, founding what became known as the "Breslau School" of physical anthropology.

The usefulness of the camp studies in fine-tuning prewar methods for postwar use was even more obvious in Vienna. Diligence during the war led to professional success: Pöch was named full professor in 1919. After his death in 1921, his assistant Weninger, author of the study of 100 West African POWs, went on to take credit for founding the "Vienna School" of physical anthropology, which continued to publish books, based on the work in the camps, into the 1950s. 
